\title{
HISTOPATHOLOGICAL STUDY ON THE INOCULATION OF HUMAN LEPROUS TISSUE INTO GUINEA PIGS
}

\author{
Tsunehiro KAWAWAKI \\ (Department of Pathology, Nagoya University School of Medicine) \\ (Suruga National Leprosarium)
}

The author has dealt with this experimental study from the point of view of a foreign body reaction occurring on the host side (guinea-pig) due to insertion of a heterogeneous morbid tissue (human lepromatous nodule). Biological tissue reactions arising then are histologically investigated as fully as possible.

The results of the experiment are as follows:

1. In the beginning non-specific inflammation takes place around the human lepromatous nodule inoculated into the subcutaneous tissue of guinea-pig. Afterwards, a specific granulation tissue appears, which is composed from round cell infiltration with leprosy bacilli, including some epithelioid cells.

2. In the neighboring lymph nodes there appears the proliferation of reticulum cells with leprosy bacilli.

3. It is remarked that a difference is recognized between young and adult animals as regards the degree of the initial exudative tissue reaction around the inserted nodule namely higher in the former than in the latter.

4. Regarding necrosis of the inoculated nodule due to the exudative tissue reaction, the change is more severe in adult animals, resulting mostly in abscess formation.

5. Some morphological differences are found between young and adult animals, regarding the specific granulation tissue arising around the inserted nodule: more myxomatous in the former, more solid in the latter.

6. Formation of giant cell begins on the 6 th day of the inoculation experiment. Initially, foreign body type is more predominant, then Langhans type and lastly giant cells with very large nuclei are encountered. 


\title{
人瀨組織のモルモツト移植に関する
}

\author{
病 理 組 織 学的 研 究 \\ 川勝常弘 \\ 名古屋大学医学部病理学教室（宮川正澄教授） \\ 国 立 臤 河 療 荃 所 (稻葉俊雄所長) \\ （昭和 34 年 9 月 7 日受稿）
}

緒論

癩菌 (Mycobacterium-leprae) が Armauer-Hansen に より結核菌 (Mycobacterium-tuberculosis) の RobertKochによる発見に先立つ 8 年前，すなわら 1873 年に発 見されてより今日に至るまで，すでに85年学経過する。 乙かるに結核菌に関する知晃，或は結核感染動物に関主 る知識の目まぐるしい発戛に反して，瀨菌については未 だその菌自体に関しても，また感染動物に関しても的確 な知見の得られていないのは勿論，その培養和よび動物 感染の成功觉ない現状であるのは周知の事実である。

そして当然のこととして世界の癩研究の中心課題がこ の二点に向けられて来たのである。

一方, 感染論の発展の途上, 特に最近においていわゆ る host-parasite relationship という概念が積極的に唱導 されるに至つて, 程の動物感染の方向も倹主側の条件を 重視する传向が現われ，例えば Cochrane ${ }^{5)}$ の脾剔出動物 使用，W. H. Feldman ${ }^{51}$ のX線照射，脾剔除，下垂体剔 H動物使用また梳 Propyl-thiouracil, Alloxan 等の使用 および Silicon-dioxide, Lipid の作用についての実験, あるいは最近の C. H. Binford ${ }^{31} の$ X線照射, Cortison 䢗 置等の動物害験はいずれもこの流れに属するものと考元 られるのである。しかし，てれらの実験はいずれも人㿗 の動物移植という中心命題を目的として行われたもので 㐫り，そのため宿主則の反応はともすれば等闌視され接 種可能あるいは不可能安の攵論じている。

本諭文において，われわれは彼等といささか視点を変

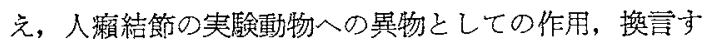
れば，特異な病原微生体を含えだ人体病変組織の移傎に 対する徨主㑡の反応という視野から問題を取报いその複 程な生体反应を形態学的に出来るだけ精細に分析するこ とにつとめた。
実 験 方 法

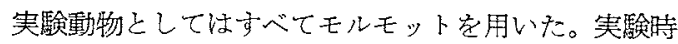
体重 $300 \mathrm{~g}$ 以上 $700 \mathrm{~g}$ 穼で成獣群として, 出生直㣪よ

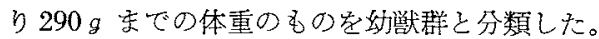

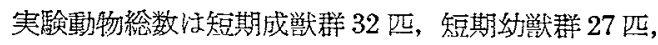
さらに長期妨獣 7 匹，計 66 匹であるが，乙の短期奻

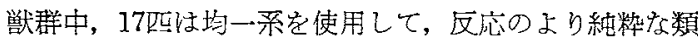
型化炎碓かるることにとめた。

飼料注緑色野菜を主として，これに敕を泿合したもの

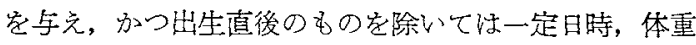
毞覞察し体重減少あるものは使用から除外した。

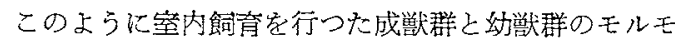
ットに人攋結節学移植後，短期群では 24 時間，48時間 72 時間，6日，10日，30日に，長期実験群は 50 日广 いし 80 日に失立，屠殺宏行った。

その総数の分有は表 1 の如くである。

表 1-1 短期実験群

\begin{tabular}{|c|c|c|c|c|c|c|c|c|}
\hline \multicolumn{3}{|c|}{ 居殺时 } & 18封 & & \multirow{2}{*}{6 日 } & \multirow{2}{*}{ 10日 } & \multirow{2}{*}{ 30日 } & \multirow{2}{*}{ 竐 } \\
\hline モルモッ! & & & & & & & & \\
\hline 成 & 獸 & 5 & 5 & 6 & 7 & 5 & 4 & 32 \\
\hline 幼 & 獣 & 5 & 5 & 4 & 5 & 5 & 3 & 27 \\
\hline
\end{tabular}

表 $1-2$ 長期実験群

\begin{tabular}{|c|c|c|c|c|c|c|}
\hline $\begin{array}{l}\text { 屠殺日 } \\
\text { モルモット }\end{array}$ & $50 \mathrm{H}$ & $55 \mathrm{\theta}$ & 60 日 & 75 月 & 80 日 & 計 \\
\hline 獸 & I & 1 & 3 & I & 1 & 7 \\
\hline
\end{tabular}

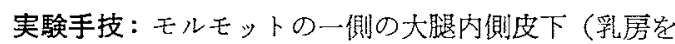
避けて）剃毛，グロシッヒ氏法により消毒し，約 $0.5 \mathrm{~cm}$ の皮切安加卡，摘出人獺結節の平均して小至大のもの学 
入し $1 \sim 2$ 針縫合した。

爾余の経過においてペニシリン等の抗生物質ならびに サルファ放は使用しなかった。

実験材料：移植に供した人癩結節注圆立駿河療養所入 所中の結節瀨の6 名の患者の獺結節部皮渵を手術空に予 いてグロシッと氏法により消毒し，皮膚と其に瀨結節を

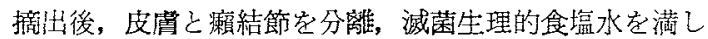
たシャーレに移し，その中で適当な大きさ，なおち小 豆大に細切しその1個は移植することなく病理組織標本 作製に資し，他を動物実験に供した。

なお费者 6 名の病型，発病年月日，レプロミン皮内反 応标よび採取部位等注表 2 に示与如くである。

表 2 移植䫅結節切除患者病歷

\begin{tabular}{|c|c|c|c|c|c|c|c|}
\hline 㭧者氏名 & 生年月日及必 & $\begin{array}{l}\text { 登月病 } \\
\text { 等月 }\end{array}$ & 入所年月日 & 满 型 & $\begin{array}{l}\text { Dharmendra } \\
\text { 度的反忍 }\end{array}$ & 楼結節切除部住 & 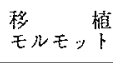 \\
\hline WO 重O & $\begin{array}{c}\text { S. } 8.7 .5 \\
\text { ล }\end{array}$ & S. 24 & 31.9 .30 & $\operatorname{Lin} 2 \mathrm{P}$ & $\begin{array}{l}\frac{48 \text { 㭙間值 }}{} \\
\frac{0}{5 \times 3} \\
15 \text { 偲 } \\
\text { (S.32.11.19) }\end{array}$ & 左第 1 指根部 & y \\
\hline 110 次O & & S. 13 & 31.5 .15 & L $3 n 3 p^{\prime \prime}$ & $\begin{array}{l}\text { 48特間俌 } \\
\text { 15日㯈 }\end{array}$ & 左大腿伸側下部 & $\mathrm{a}, \mathrm{c}$ \\
\hline & $\hat{o}$ & & （転所） & & (S. $\overrightarrow{32.11 .19)}$ & 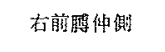 & $\mathrm{g}$ \\
\hline 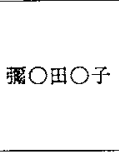 & $\begin{array}{l}\text { T. } 9.9 .27 \\
9\end{array}$ & S. 12 & 29.3 .20 & $\mathrm{~L}_{3 n 3 p}$ & $\begin{array}{l}\text { 48待閣値 } \\
\frac{3 \times 3}{-\frac{3 \times 5}{5 \times 5}} \\
15 日 \text { 值 } \\
\text { (S. } 32.11 .19)\end{array}$ & 左前膊外揑 & b \\
\hline$=0$ 春O & $\begin{array}{c}\text { T. } 9.8 .10 \\
\text { \& }\end{array}$ & S. 12 & 32.7 .17 & $\operatorname{Lan}_{3} p$ & $\begin{array}{l}\text { 48時間值 } \\
\frac{0}{4 \times 4} \\
15 \text { 日值 } \\
\text { (S. } 32.11 .19)\end{array}$ & 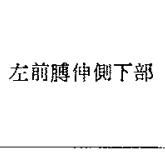 & $d, e, f$ \\
\hline 森O 武O & $\begin{array}{c}\mathrm{T}, 10.12 .10 \\
\text { ㅇ }\end{array}$ & S. 13 & 25.5 .31 & $\operatorname{L} 3 n 3 p^{\prime \prime \prime}$ & $\begin{array}{l}\text { 48時問细 } \\
\text { 14日值 } \\
\text { (S. } 32.11 .19 \text { ) }\end{array}$ & 左置毛上部 & 1 \\
\hline \multirow[t]{2}{*}{ 鈴○繁○郎 } & M. 13.2 .2 & \multirow[t]{2}{*}{ S, 28} & 33.2 .25 & \multirow[t]{2}{*}{ L $3 \times 3 p^{\prime}$} & \multirow{2}{*}{$\begin{array}{l}\text { 48時間值 } \\
15 \text { 日值 } \\
(S, \overline{33} .2 .27)\end{array}$} & 右大政缩側 & $\mathrm{m}, \mathrm{n}$ \\
\hline & & & (陆大所) & & & 右前膊内測 & $\begin{array}{c}\mathrm{g}, 6 \\
(10 \text { 日目) }\end{array}$ \\
\hline
\end{tabular}

実験作製：実験モルモットは予定された一定日時にお

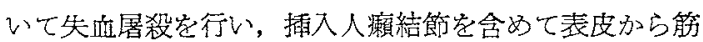
層までを摘出し，割を加兑，肉眼的に観察し，直ちにカ ルノフ固定液に投入し，また同時に適出側の鼠蹊部リン パ節をる摘出，観察を行い，同時化固定を行いパラフイ ン切片を作成し，へマトキシリン・エオジン重染色，フ ザン染色 (ハイデンハイン氏変法)，エラスチーカ・ワ ンギーソン染色 (以後 V G 染色), パップ氏鍍銀染色, チール・ネールセン氏菌染色（石原氏 ${ }^{12)}$ 法によるトルオ ールによる脱パラを用いた），また矢崎式螢光顕微鏡的 染色（清水 ${ }^{31 \sim 32)}$ によるY S 法）を行い検索に供した。

\section{実 験 成 績}

今, 全例にお㧍る所見觉詳細に述べることは繁雑にな
るのでその大体の所見は 表 3(1-7）に表示し，その 中, 代表的な症例の組織学的所見定例記す机ば次の如く である。

まず短期成獣群において注実験勳物番号 e について述 ベる。

e 1 (移植 24 時間後, 屠殺例)

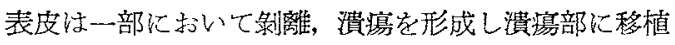
結節が露出している。この露出せる結節の表面化好中球 它含えだ Debris および線維素網を認める。移稙結節は ほとえど全部，壊死に陷り極く僅かに核染を残している 個所も存在するが，大部分は好中球の集簇ならびに浸潤 によって占められている。その周囲には好中球定主体と 乙て広沉な炎性澄出物を認め，乙の变化が表皮下の膠原

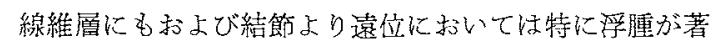


言 3-1 24 時 斛

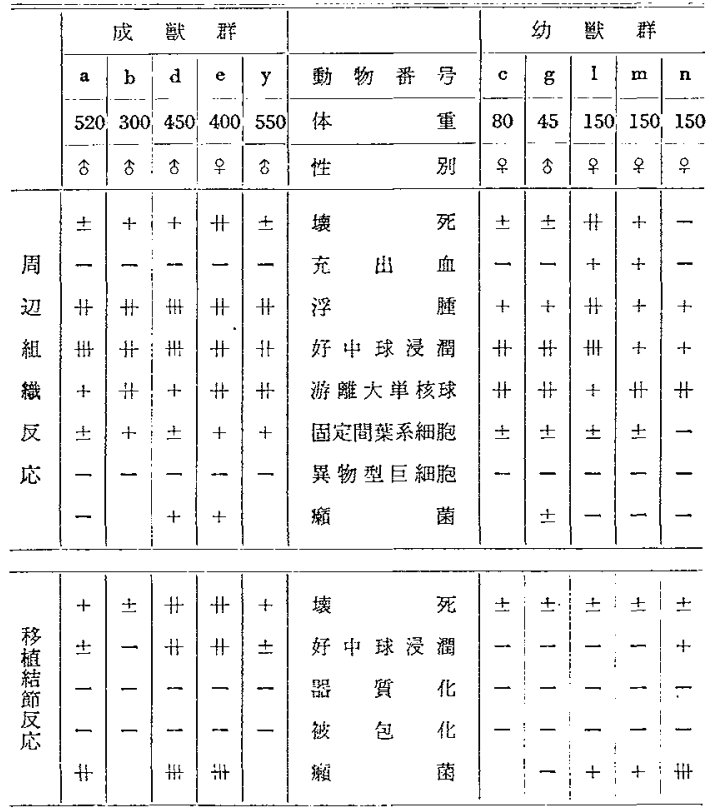

表 3-2 48 時 閶

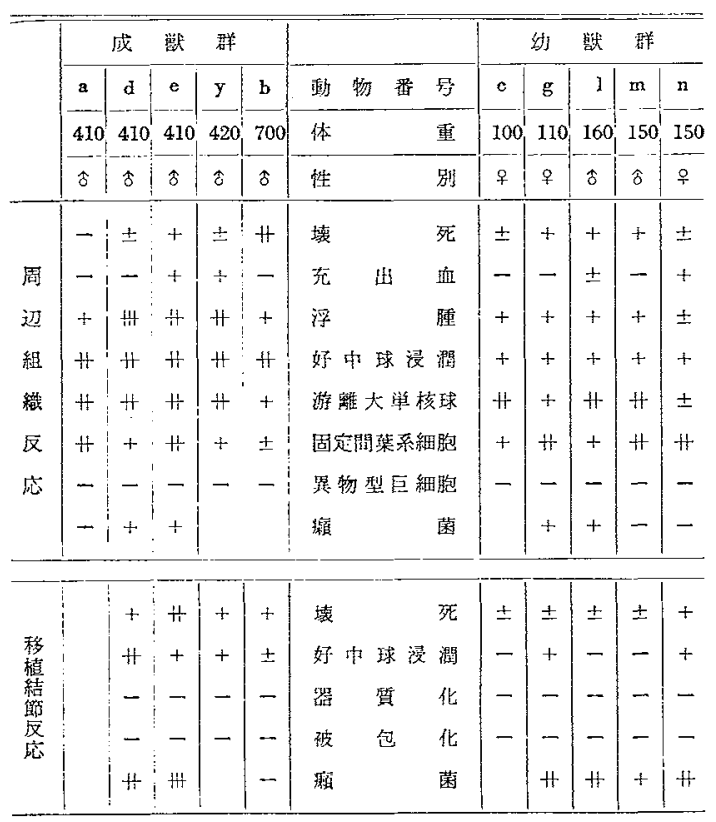

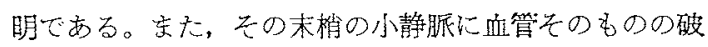

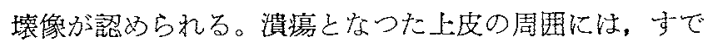
に一部再生像が熟められる。

e 2 (移植 48 時腮後, 屠殺例)

表皮は一部溃瘍を形成しそこに contamination
王 $3-3 \quad 72$ 時 間

\begin{tabular}{|c|c|c|c|c|c|c|c|c|c|c|c|c|}
\hline & \multicolumn{2}{|r|}{ 成 } & \multicolumn{2}{|c|}{ 獣 } & \multicolumn{2}{|l|}{ 群 } & \multirow[b]{2}{*}{ 聈 物 潘 } & \multirow[b]{2}{*}{ 号 } & \multicolumn{4}{|c|}{ 妙 獣 群 } \\
\hline & $a$ & $b$ & d & e & $y$ & $\mathrm{n}$ & & & c & $\mathrm{g}$ & 1 & m \\
\hline & 300 & 350 & 500 & 450 & 500 & 440 & 体 & 重 & 100 & 120 & 180 & 160 \\
\hline & 우 & 우 & कृ & $\hat{\sigma}$ & 우 & $\hat{o}$ & 性 & 別 & 우 & $\hat{o}$ & $\hat{\delta}$ & 우 \\
\hline & - & + & - & + & + & + & 壊 & 死 & + & - & \pm & \pm \\
\hline 周 & - & + & - & \# & - & + & 充 & 典 & + & - & - & - \\
\hline 辺 & \pm & + & H & \# & + & \# & 浮 & 朢 & $\#$ & \pm & - & \pm \\
\hline 組 & + & + & + & \# & + & $\#$ & 好中球浸 & & + & + & + & + \\
\hline 織 & + & \pm & \# & H & + & \pm & 游離大単核 & & H & \# & H & $\#$ \\
\hline 区 & 4 & - & H & H & + & \pm & 固定閤萁系細 & & $\#$ & \# & + & $\#$ \\
\hline 忍 & - & - & - & - & - & - & 巽物 型巨盉 & & - & - & - & - \\
\hline & + & & H & - & & - & 瀬 & 菌 & & \pm & + & + \\
\hline & \# & + & & H & + & \# & 㩍 & 死 & \pm & \pm & + & + \\
\hline $\begin{array}{l}\text { 䄷 } \\
\text { 䅦 }\end{array}$ & + & + & & + & + & H & 好抖球浸 & & \pm & \pm & \pm & + \\
\hline 結 & - & - & & \pm & - & - & 器 質 & 化 & - & - & - & -- \\
\hline $\begin{array}{l}\text { 忞 } \\
\text { 底 }\end{array}$ & - & - & & - & - & - & 包 & 化 & - & - & - & - \\
\hline & & & & - & & - & 廁 & 菌 & & H & + & + \\
\hline
\end{tabular}

表 $3-46$ 日

\begin{tabular}{|c|c|c|c|c|c|c|c|c|c|c|c|c|c|}
\hline & & 成 & 唯 & & 磰 & & & & & 约 & 獣 & 群 & \\
\hline & a & $\mathrm{d}$ & e & f & y & b & 㸝物 番 & & c & $\mathrm{g}$ & 1 & $\mathrm{~m}$ & $\mathbf{n}$ \\
\hline & 330 & 400 & 400 & 410 & 550 & 550 & 椺 & 重 & 200 & 150 & $160^{\circ}$ & 120 & 200 \\
\hline & 오 & f & $\delta$ & 우 & $\delta$ & q & 性 & 別 & q & 8 & \& & 오 & 우 \\
\hline & H & \pm & $\stackrel{ \pm}{=}$ & + & + & H & 㻮 & 死 & \pm & + & \pm & $-i$ & - \\
\hline 周 & H & + & Hit & \pm & H & + & 充 出 & 血 & - & + & + & $-\vdots$ & - \\
\hline 辽 & \# & H & $H$ & +1 & + & + & 浮 & 腫 & - & + & \pm & \pm & $\#$ \\
\hline 組 & 䉼 & H & \# & \# & + & \pm & 好中球浸 & & \pm & + & \pm & \pm & \# \\
\hline 䅧 & +1 & + & \pm & + & + & + & 派離大単核 & & + & H & \pm & $H$ & + \\
\hline 反 & $H$ & $\mathrm{~m}$ & int & H & m & - & 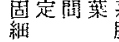 & & \# & H & m & $H$ & $\#$ \\
\hline 忘 & HI & \pm & + & + & - & - & 珙物型巨細 & & H & - & + & - & - \\
\hline & + & H & H & H & & & 䉛 & 菌 & & \pm & + & - & + \\
\hline & & & & & & & - & & & & . & & \\
\hline & + & Ht & H & H & H & & 壊 & 死： & $H$ & + & + & + & $H$ \\
\hline $\begin{array}{l}\text { 䔟 } \\
\text { 植 }\end{array}$ & $H$ & H & H & \# & H & & 好中球浸 & & + & + & + & + & $H$ \\
\hline $\begin{array}{l}\text { 結 } \\
\text { 節 }\end{array}$ & - & + & $H$ & + & + & & 器 罂 & 化 & $\#$ & - & H & $H$ & - \\
\hline 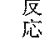 & - & - & - & - & - & & 被 包 & & - & - & - & - & - \\
\hline & H & H & H & Hit & & & & 菌 & & H & \# & $\#$ & \pm \\
\hline
\end{tabular}

起し激しい出性炎庭像宗示。潰榎底に移植結節が露 出し，その結節内には血等成分学含九だ好中球の集簇㮍 およびその一部に好中球の結節内への浸潤を認める。ま た結節は広沉な部分に壊死を来し，核染ならびに線維構 造至失う部分があり，潰癔底に露出する以外の結節周囲 
表3-5 10 日

\begin{tabular}{|c|c|c|c|c|c|c|c|c|c|c|c|c|}
\hline & \multicolumn{2}{|r|}{ 成 } & 獣 & \multicolumn{2}{|l|}{ 群 } & & \multicolumn{2}{|c|}{ 约 } & 獣 & \multicolumn{2}{|l|}{ 群 } \\
\hline & b & d & e & $\mathbf{f}$ & $y$ & 動 物 媌: & & c & $g$ & I & $\mathrm{m}$ & $n$ \\
\hline & 550 & 410 & 500 & 420 & 550 & 体 & 重 & 200 & 120 & $200^{\circ}$ & 170 & 120 \\
\hline & $q$ & 占 & 占 & 우 & $\hat{o}$ & 性 & 別 & & $q$ & 3 & $3:$ & io \\
\hline & + & \pm & \pm & \pm & + & 壊 & 死 & - & \pm & - & $-!$ & + \\
\hline 因 & - & - & - & - & $\#$ & $H$ & 欰 & - & + & - & \pm & - \\
\hline 讱 & \pm & \pm & \pm & \pm & + & & 連 & + & \pm & \pm & - & + \\
\hline 租 & + & \pm & + & + & + & 好中球浸 & 濯 & + & + & - & \pm & + \\
\hline 織 & + & \pm & - & - & + & 游離大学核 & & H & - & \pm & + & + \\
\hline 反 & m & 册 & m & m & m & 固定間独系細 & & $\mathrm{H}$ & 䐗 & $H$ & i:t & Hit \\
\hline 空 & $\#$ & - & \pm & + & - & 巽特型巨細 & & - & 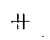 & H & - & H \\
\hline & & H & $\#$ & + & & 濑 & 菌 & & + & + & + & + \\
\hline & $\div$ & H & H & H & Hit & 壊 & 死 & H & \pm & \pm & H & $H$ \\
\hline 䔟 & + & $\#$ & H & H & 㖄 & 好中球浸 & & + & + & \pm & + & $H$ \\
\hline 緢 & H & + & H & H & + & 器質 & 化 & $H$ & \# & Hit & $\div$ & $H$ \\
\hline & - & + & + & - & - & 包 & 化 & - & - & - & - & - \\
\hline & & + & + & $\pm i$ & & & 菌 & & & & $H$ & H \\
\hline
\end{tabular}

表 $3-6 \quad 30$ 日

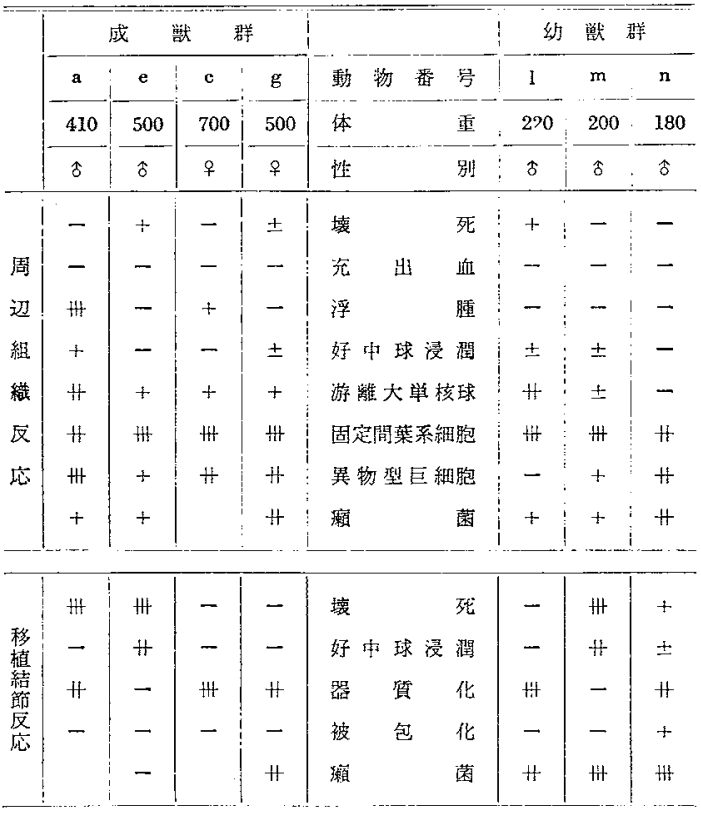

組織は広汎な炵性淬出性变化で占められる。とこるどこ ろ debris，懐死塊および好中球の集笶を見る。その最外 層においては後に述べる妙獣の場合，著朋ではないが毛 細直管の出茅を見，から，ところどころに毛細血管の内 皮の腫大を認める。VG染色から晃ると移植結節の線維
表 3-7 長-期実験群

\begin{tabular}{|c|c|c|c|c|c|c|c|c|}
\hline 動 物 番 & 号 & 0 & $P$ & $Q$ & $\mathbf{R}$ & $\mathrm{S}$ & $\mathbf{T}$ & $\mathrm{U}$ \\
\hline 重 & (g) & 270 & 290 & 210 & 160 & 140 & 170 & 150 \\
\hline 栍 & 別 & $\hat{8}$ & $\hat{\partial}$ & $\hat{s}$ & 웅 & 웅 & $q$ & $\hat{\sigma}$ \\
\hline 实 䉖 日 & 数 & 60 & 80 & 60 & 55 & 50 & 60 & 75 \\
\hline 䁾 & 死 & \pm & - & $H$ & + & - & - & m \\
\hline 毛䄄管 新 & 厂尘 & H & H & + & + & \pm & + & \pm \\
\hline 線 維 增 & 生 & $H$ & \pm & + & \pm & $H$ & + & + \\
\hline 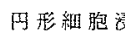 & 浸潤 & \# & it & + & \pm & \pm & \pm & \pm \\
\hline 大蛘枮細 & 胞 & $H$ & H & $t$ & $H$ & + & $H$ & 4 \\
\hline 類上皮細 & 胞 & \pm & \pm & + & 4 & \pm & H & H \\
\hline E細 & 胞 & + & + & $f$ & \# & - & H & \pm \\
\hline 潩 & 壮落 & $H$ & + & - & - & H & H & - \\
\hline 朖 & 嫣 & - & - & + & - & H. & + & - \\
\hline 包 & 化 & - & - & + & - & - & - & + \\
\hline
\end{tabular}

構造好比較的保持されており，血管の弾力線維も保持さ れている。さらにアザン染色では網状織線維の細工が残 存, 移植結節内心癹如礼学。

\section{e 3 (移植 72 時間後, 屠殺例)}

表皮の一部汇䐝室安形成し表皮下の乳頭層に注単核細

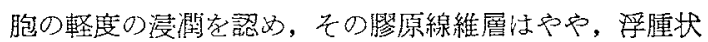

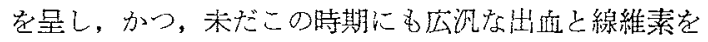
含えボ答计性炎症像が見られる。また，同時に肉芽織の 形成も僅かなが方活動的となり毛細血管の出芽もところ どこるに胃られる。しかし，それも広沉な答出性炎症像 に掩わ和て目立たない。

移植結節はほとえど全体に滾死を呈し，大部分が好中 球または Debrisと化し，正常の核染它もつたすのは少 い。まだこの時期には填死に陷つたのみで周囲よりの肉 茅織の侵入は認わられない。

V G染色では移植結節は一部に線維組織の残存を見る が，大体においてその構造は破壊されている。なた，

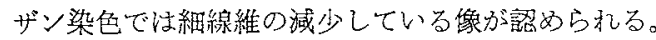

\section{e 4 (移植 6 日後, 屠殺例)}

再生した表皮は一部に拉いて真皮内に樹枝状に近い形 態の堌生像を呈し, acanthosis の像を示している。その 皮下乳頭層些びに膠原線維層には好中球等の浸潤が翟め 吕光。

移植結節の周囲組織ほ一部に広沉，加つ，高度の岑目 並びに線維素網の析出があり，その線維素網に対して周

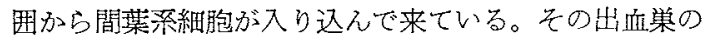
外層には一部には㷋性出出性区念加残存しているが，そ の大部分は線維化を伴つた炎性肉芽腫壳もつて構成さ秃 


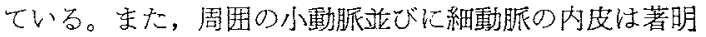

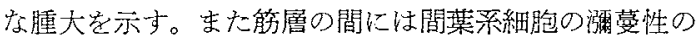
増生打よび筋閣への侵入が見ら扟，同時に筋細胞の染色 性注瑥基性江傾き，形も小型化し，しばしば筋原性と考 えられる巨細胞の出現がある。

これらとは別個に移植結節に接して異物型巨細胞を数 垈，散見しうる。

移植結節は注ぼ，全体に和たつて壊死に陷り，そのほ とんぞは好中球汸浸潤し、脤瘍様になつている。この膿 瘍化した結節と周围の肉苏織と接主る部分にやや，大型

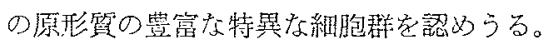

V G染色ではほ上んど原組織の組織構造は失われて扔

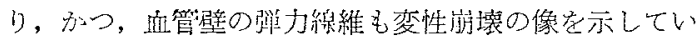
る。おたアザン染色で見ると網様構造が消失し，かつ，

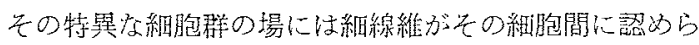
れるもののようである。

e 5 (移植 10 日後, 屠殺例)

表皮就度の acanthosisを示し，絗胞浸润はほとえぞ

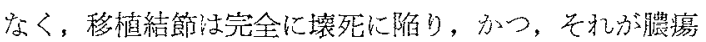

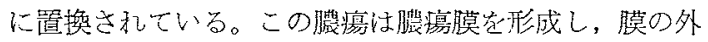
側には一部に出血栄安認め，その部に肉第織の侵入があ り，さらに气の外層は極好て少数の異物型巨細胞を含え だ線維組織によつて围に繞される。しかしこの場合でも膿

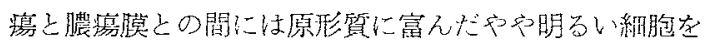
少数なが放散見しうる。

爾余の部分では，一般に浮腫が減少し增㙛性変化がこ 机変つて来ている。

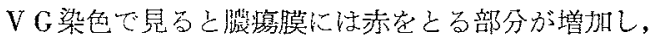

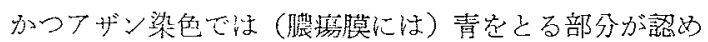
られる。

e 6 (移植 30 日後, 尿殺例)

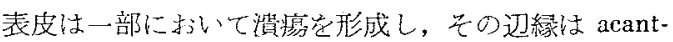

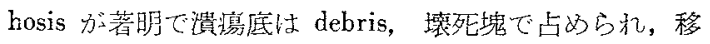

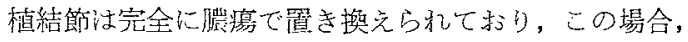

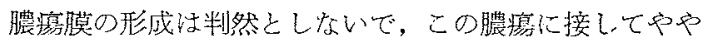
大型の原形貿に富えだ特烡な細胞群が非常に多量に出現 しており，そ礼らの細胞群に湿つて定型的ないし非定型 的の異物巨細胞岩見る。

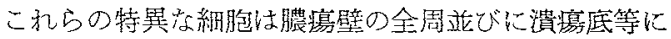
有面管肉芽織に混つて相当, 広範囲にわたつて認的ら れ，かっこれらの緗胞嵒の間質は短期纤獣に較べてや や密である。幼獣の場合の如く粘液腫様の態じを与える

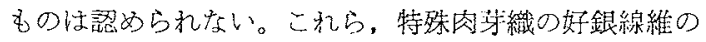
発育は非常に良好であつて, 細線維がこ㧈らの細胞にま
つわりつく如き感を与える。

またV G染色で見ると特異性肉芽織内にはとこるどこ ろに弾力線維が種々の形に奖形離断して存在するの定認 める。

短期纤獣群儿おいては実験動物番号1について述べ る。

11 (移植 24 時間後，屡殺例）

表皮は一部剥脱し，その部に出血在認的る。さらに剥 脱した表皮の直下に法好中球を主体とする㷋性区応が見 ら机，その直下はやや捊腫状を呈し，さらに皮下脂肪織 内には血管の充盈放よび単核球の漻出老認め，さらにそ

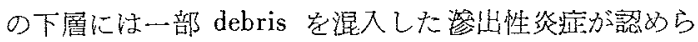

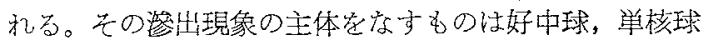
で，そ礼に液牲成分が少量伴つてをり，同時に核が類円

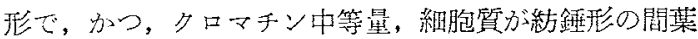
系細胞の增殖を認める。

これらの好中球，単核球，間葉柔細胞が移植された組 織塊周辺の一部に附着している。

移植結節組織ゆ極好て呰少な部分に好中球の侵入した 像定認める。移植結節注大体比打いて原型を留めている

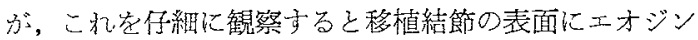

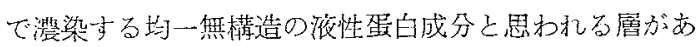

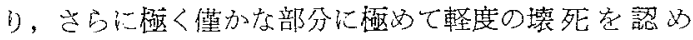
る。しかし，全般には非常に良く原結節組織の構造は保 持されている。吻諭, 被包化, 器賢化等致認奶柇な い。

V G 染色に米いては移植絬節周囲にはフクシンで染宋 りやや微細線維状となつた浮缠の部分があり、移植結節 で注染する線維構造がよく保持されている。

アザン染色に和いては移植結節法青色をとる䌊維構造 並びに絈線維による網状楧造が判然としている。

移植結節のエオジンで均一無構造の部分はフザン染色 では赤染する。

I 2 (移植 48 時䦩後, 屠殺例)

表皮には変化なく表皮下の膠原線維に一部砖化が認ぬ られ，さらにその下層の脂肪織炕細い血管の光盈が非常 に著明で，槰合系の周囲には壊死物犋乙好中球，単核球 等の細胞浸潤が恚められる。さらにとの下層は線維芽細 胞の増殖が見られ，同時に楥植結節の周囲に浮腫の名残

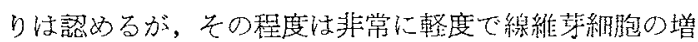
生々共に新生毛細面管の增生が認如られ，その中に毛細 直管の出芽之解釈され西像が多く認邓られる。

更にその肉芽織の動きの中には単球，プラスマ細胞の 
浸潤等一部，線維素網の中には好中球も散見される。

移植結節では一部に明らかに好中球の集簇をなした浸 潤が認められ，また，他の部ではェオジンに平等に濙染 する無構造な物蟹も認められ，その周囲に僅少の線維素 網の中に好中球炎認方る。さらに䔟裇結節の構造もや之 乱机ている。

V G染色に和いては坔色をとる線維配列の乱れが見 ら，移植結節周团では大体，赤色をとる線維によつて囲

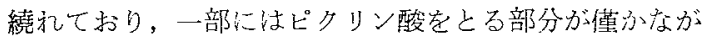
ら認奶られる。な移植結節の弾力線維の状態は保持さ れている。

アザン染色におらいてこの部の組線維による網様構造 は大体においてよく保持されている。

13 (移植 72 時間後, 屠殺例)

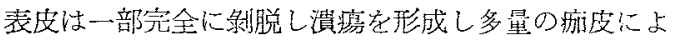

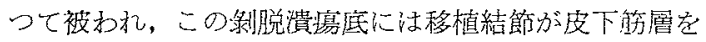
架破して筋層に至るまでを占めている。他の部の表皮下 にはプラスマ紐胞，リソ，球，単核球等定主体とした細

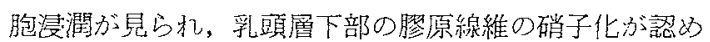
られる。さらに硝子化を示した膠原線維の上層には表皮 成分の再生が一部晃ら机る。

移植結節と往主側の間には一部に著明な出血と毛細血 管の高度の允盈および孚腫が見られ，さらにその線維素 網の形成が著明でその部に細胞の集積が見られ，これら

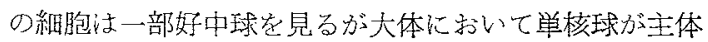
をなしており，48時間の像と同様に毛細血管の出芽が見 ら秃，まな線維第細胞の再生为活登となり，大体におい て，移植結節心対して直盾の方向に毛組血管の出笑が見 ら彷ももが多い。

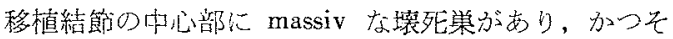
の周辺の処々にエオジンに淡染する壊死部が散胃され

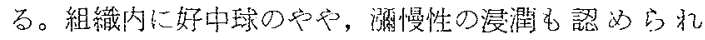
当。

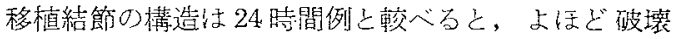
がすすみ，VG染色において楥植結節中心部は無棈造に 黄染する狂その中に血管が残存している。

全体に結節の裤造が乱机，一部では思明組維上りの肉

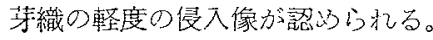

またフザタ染色で見ると全体に移植結節の網様構造 が保持されている。一部の周同組織には線維索絧の形成 が著明である。

14 (移植 6 日後, 虎殺例)

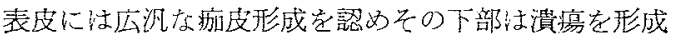

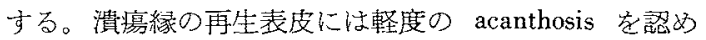

る。漬滈底には脂肪織が露山出しており，その部に壊死物 質，故中球浸潤等の contamination 像安見る。

さらに脂肪織の下層には移植結節との間に広汎な肉芽 織の形成肪あり，所謂，浮腫，好中球温潤等の出性反 応が非常に少なくなり，移植結節との校く近接部に黛少 ながら㒛められる程度である。さらに肉芽織の周囲には この時期では巨細胞が数個出現するようになる。さらに その周辺の細血管はいずれも内皮が腫大しており，中に は制脱学示しているものもあり，また，肉第織祘辺の小

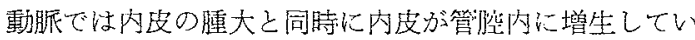

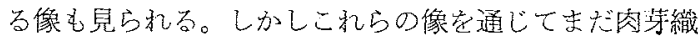
中の毛䋖血管と毛細血管との間には硝于化した翏原線維 は認められない。

移植結節部では壊死の部分が多くなり，かつ好中球の

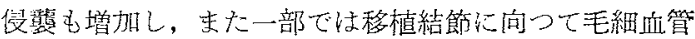
堂伴つた肉第織の侵入像も認められる。

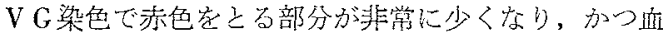
管の弾力線維も難染性の傾向圭示す。また，ナザン染色

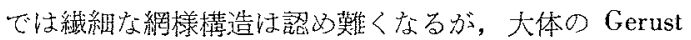
生認别られる。

15 (移植 10 日後, 屠殺例)

表皮は一部に和いて著明に acanthosis 起しふつ， acanthosis 部表皮の直下には，異物型巨細胞方多数諮义 ら秃，その部に類円形の核でクロマチンにややそしい紡 鍾形の細胞の集簇妾認》る。

こ和らは一程の類上皮細胞に近い形態夌もつている。 その中にはプラスマ細胞の湿在安認引る。6日例に才小

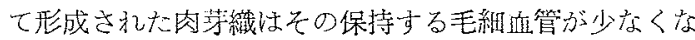
り，一部では明ら方儿細線維の增加学是る。

移植結節はほとえど原型を留めず，線維組織方よび肉

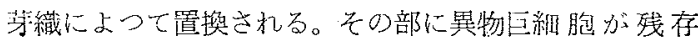
し，また近辺に塆死に陌つた毛根の存在与る事办方僅か

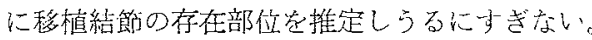

これらの肉等織の周国にはやや，浮腄状になつた綵維 芽絸胞の層があり，一兒粘液腫様の感壳与克る。

V G 染色ではこの粘液酎様の部分は赤染し, 線維織で 置换された部位も赤色它とる。さらにアザン染色では粘

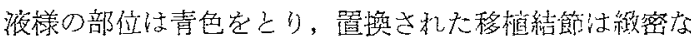
線維の集䡒としてみとめられる。この例ては6日例に見 られた的管の变化は認好られない。

16 (塖植 30 日後, 屠殺例)

表皮はほとど変化なく，乳頭層には単核球扊主体と

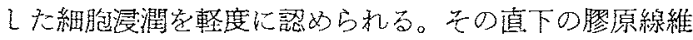
はやや，エオジンに濃染の傾向を紫び，その琹原線維層 
から筋層にかけて特殊な肉芽織の形成を見る。この肉芽 織俚一部に debris 方あり，間筫に富み，有血管の肉芽 織が debris を团結し，その周辺に行くに従つてやや粘 液腫様の感のある間質が増加している。また，その周辺 部汇類円形乃至棈円形の大型の核を有し，かつクロマチ

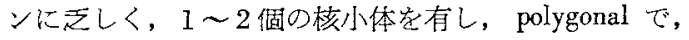
やや明るい大型の細胞質を有する特異な細胞が集簇を成 して出現する。

これらの細胞群苂追究すると, 一部では組織球性細胞 との移行像をも認为らる。

非常に定型的なるの核細胞質が䄉細な顆粒状万至空胞 状であつて，いずれにしても非特烡性の肉莱織には出現 艺見ない特異な細胞群と認めねばならない。かつ,こ机 らの細胞群の間の間質は粘㴭腫様である。

非特異性肉芽織中の細動脈の血管の内皮はいずれも腫 大宗し，かつ，小動脈に抢いては6日例に見られたと 同椂に内皮の腫大とその内皮の内腔に対しての島嶼状の 增生が見られる。

これをV G 染色で見ると，䈯換された特殊性肉芽織の 一見, 粘液腫㥞の部は赤色をとるが，特殊細胞䛨の間に 子細い赤色をとつた線維が㑇められる。

\section{短期実験群の所見に関する小括}

今, 実驗成續の主要な所見を小括するに当つて，一忍 移植された人瀨結節㐋のものの移植前の組織像について 簡単にられておきたい。

実験に使用した人瀨結節はいずれも第 6 回国際らい会 議融における Lepromatous-Type に属し，表 2 に示与如 き臨床所見を示したものであるが，その病理組織像む同

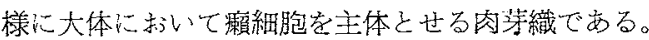

この中に山○重○等, 線維化が強くややその泡沫細胞 が少く, が菌も割仯いものと, 鈴○繁○郎, 二○春 ○等に見られた泡涞細胞が著明で，線維化就よび円形細 胞浸解少く，攋菌の多いものなど，幾分の相違は認めら れ，かつ癩球はいずれもこれ安ほとんど欠いてはいるか その肉芽腫形成の組織像に和いて明らが TubercloidType とは異つたすのであることを明白にし，かつチー ル・ネールセン染色拉よびY S 法にて菌定確実に証明し 得たものである。

かかかる結節をモルモット皮下に移植した揚合，これに 対する骨所的反心は動物の老幼に上つて，こまかい点で の相違梳方が，打よそ異物性炎の通則に徉つて，まず

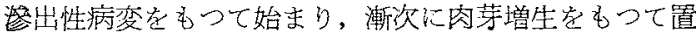
き舞えら礼，線維化ないし被包化に赴く。
この間，被移植結節自体はしばしば壤死以陌り，また 潰晹の形成を来して，楼菌感染它混合し，化胀性变化の 強摆される場合もある。

以上の比較的単純な一般的経過の他，㘔結節移植に際 して，やや，特買的上考无られるのは肉芽織の形成㧍よ びその性状であって，この点について特に30日に拈ける 肉芽織の所見家中心にやや詳しく総括したい。

10日においては一般的な增殖反応の一環として韭特異 的な肉第織の形成を見，ただ，その中に癩菌の多数の残 存を見るに止まるが，30日の所見では，その棐特異的肉 芽織内に特異的な形態を示す細胞集皦が出現する。すで に各個所見の項で精述したように，その場合，定型的な

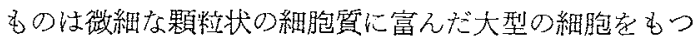
て構成され，その中に菌富有し，かつラングハンス型 或は異物型巨細胞の混在を見るのである。

この特異的肉赫織の形態においてむ成獣と幼獣とでは 若干の差異を翏め，成獣においてはその肉茅腫は緻密な 構造定もち，かつ，細胞自体が相互に密着して排列する

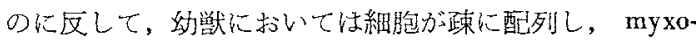
matous な感を与える。

経時的に以上を緾めると，

24時間ではいずれもまず好中球を主体とした浮腫，充

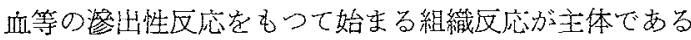
が，炎の程度は明らかに幼獣において弱い。徉つて好中 球による初期飡菌像も成獣において著明に見られるもの である。

末た, 一方, 移植結節の形態的变化, 特に壞死も成獣 において強く，好中球の移植結節内浸潤も成獣で強い。

48時間にても大体，このような形熊像が主体をなして おり，成獣に打いては依然乞して強い好中球參出，浮埂 がめだつ。しかし，この時期になると，棇出性病紧の周

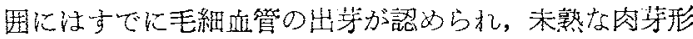
成の動きが成獣，幻獣共に見ら机，尘た移植結節周囲の

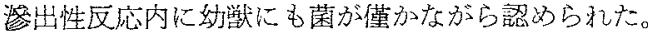

移植結節に打いては，奻獣の場合，僅加にその2例に 軽微の好中球浸浱が見られ始めたに止るが，成獣におい

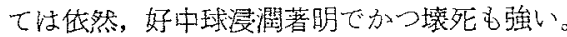

72時間においても低然として济出性反応は旺盛で，や はり成獣に拟いて強度の反忘を兒ると同時に，移植結節 の周囲には線維素繹に細胞集穦が起り，その外周に有血 管の肉芽織が相当，目立つて反応して来るのが分る。

すなわち，この時期においては表 3 の如く游噰の大算 核球，周定の間葉系細胞の增生が特汇目立つわけであ

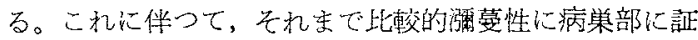


明しえた濑菌が減少或は消失して，その牙見が著明でな くなるような印象炎与える。

移植結節においては特に成獣に著明な墂死，好中球の

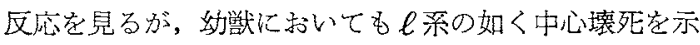
すものが見ら礼るに至るが，一般に壊㱜の程度は弱い。

6 日に至ると, 上述の様相は大きな变革空生じて，正

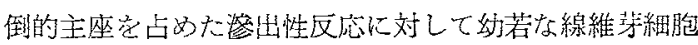
炎中心とした所謂，固定間葉系細胞の活動が著明とな り，従来，陆性反応に覆われていたこれらの増殖性反 応が相当強くなると共に，ここに始必て異物型巨細胞の 影著な出現を見る。同時に一旦，減少した感のある区心 栄内の癞菌も多くなる。移植結節の滾死，好中球浸潤が 進劣と其に今まで見られなかつた器質化が現われて来

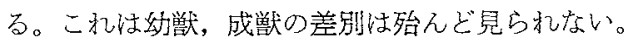

10日目においては，成獣，奻獣共に璔殖性反忘が主座 をらめるようになり，異物型巨細胞も出現著明で，かつ 癩菌も初期好中球喰菌現象を脱して単核球に哈菌される 状態となる。

移植結節は成獣においてほ汪完全に壊死に陷り，一部 で被包化，一部では著明な器質化，さらに一部で注小膿

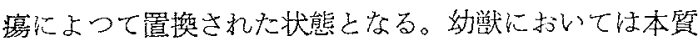
的な㑯向は同一であるが，壊死の程度は成獣に比して軽 度で，未だ原結節の基本構造の残存を認める。

30日に至ると，なた一段と变貌を遂げ，すでに笭出性

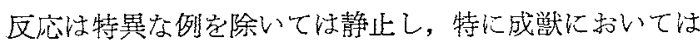
一部リンパ球の浸潤が著明となる列がある。この期に主

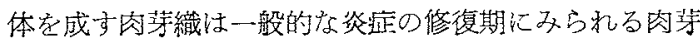
織と甚だ趣定異にしている。

これについては別記するので記載を省略し，ただ瀨菌 がこの肉芽織中に必らず見出された事を附記するに止め る。

移植結節は成獣，幼獣豆に一部は完全に膿瘍と化し， 一部は器質化して原型を止めず，幼獣の一例は被包化と 器質化の混在学見る。

\section{長期実験群については}

以上の短期実験の実駼結果より，30日に衫いて特異性 肉芽の出現を見たので，この形態的推移々变貌它迫求す るために，表 I-2 の如き実験を行つた。この場合短期 実駼群の結果上り幼獸群に主力を注いだ。その結果は袁

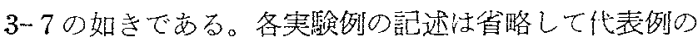
攵造べる。

07 (移植 60 日後, 居耓例)

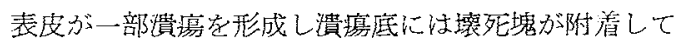

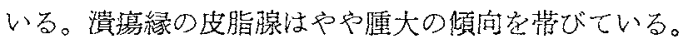
その漬瘍底の壞死塊の直下には毛細血管の新生を伴つた 軽度の肉芽織形成が見られるが，さらにその深層怡粘液 腫様の組織によつて上められ，その処々に固定間葉系細 胞を主体とする結節の形成が見られる。

この結節髢成に関与する主なる細胞群立びに粘液腫倳 の組織内に存在する大型の細胞譬は，いずれる胞体がや や抗酸性で大きく，核は類円形ないし紡鍾形で，類上皮 細胞の性格に近い核の忹状を有している。さらに染部の 筋層においては筋肉間の特に血管周辺部に著明な細肘浸 潤安双る。

\section{Q7 (移植 60 日後, 屠殺例)}

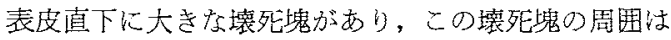
半代被包化さ礼ているが，被包化部分には肉芽緎の新生 が嚾ふながら見られ，その周囲は固定間葉系紐胞による 結節の形成之血管周囲の細胞浸潤とが锠引られる。この 場合，特に結節内には単核の巨細胞が混入し，処によつ ては2核の巨細胞も出現しているが，明らふ㐫ラング八 ンス型および異物型の巨細胞は見られない。

R 7 (繁植 55 日後，屠殺例)

上皮は一部に軽度の acanthosis 在起し，中は引皮脂 腺の腫大が見られ，この表皮直下には固定間葉系細胞が

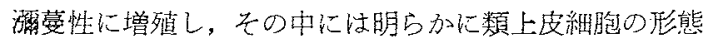
を示するのむ心る。その游萝性に堌殖した細胞の中心は 壞死によつて占められていて，偯死垥囲には単核の巨細 胞の出現を見る。この場合明らか心結節形成は兒られな い。かつ,リンハ球の浸潤は割会に軽度である。一部に おいてやはり粘液腫様細胞の中に特殊な大型の細胞ぶ蹯 に出現している。

\section{U 7 (移植 75 日後, 屠殺例)}

表皮直下に恐らく移植結節自身乙思われる一部脂肪学 残し，かつ原結節の棈造を残した大きな填死塊完見る。 これを中心にへマトキシリンで濃染する部分が存在する が，大体にエオジンで均望に染色されて凝固填死の形を とつている。この結節の周辺はやはり特殊な肉芽織で占 められているが，この湯合非常に反応要㮦が少く，特殊 な固定間葉系細胞，類上皮細胞，巨細胞等が少くかつ， リンパ球を極めて之しい。

長期成獣群においてその四蹊りンパ節におおる特異な 所見を得たので述べる。

R 7 (移植 55 日，屠殺例のリン八゚節)

大部分の㲽縁洞は正常に保持されており，皮留の二次 小節の出現も著朋であるが，明らかに暗核を伴つたフレ ミング型の二次小節の出現は乏しく，大部分は克笑な 
いし移行型である。

一部の皮質に出いてはその細絪細胞が非常に睡大し， 特殊な細胞群を形成している。この中には明らかに多核 の巨細胞を湦入している。ただこの多核の巨細胞は核の クロマチン量少く，核も腫大してむり，またその配列も 一般には興型的なラングハンス型ないし異物型とは異つ た形態をとつている。この腫大した皮貿のために践索が

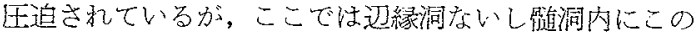
種の増生侵入はない。

P 7 (移植 80 日，屠殺例のりンパ節）

腫大学示し辺縁洞に住一部正党構造定保持するが，大 部分は辺緣洞内には非常に腫大乙，胞体がやや，㧧酸性 で核のクロマチン量の少、細網細胞によつて占放られて いる。皮質の二次小節の反応は著明で，明ら方に明中心

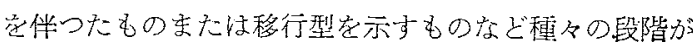
が見られる。この中で一部皮暂内に細網細胞湆增生して 結節安形成しているものもあり，さらに辺縁润と皮質と

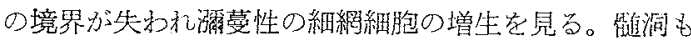
ほとスどこれらの腫大した細網細胞で理以つくされ，た わに一部の成索忹压迫さ㣗ている。

\section{長期実験群の所見に関する小括}

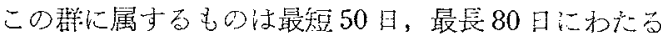

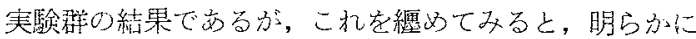

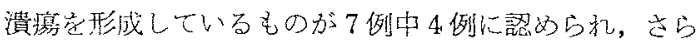
に脤寔形成 3 例とい子゙れも或る程度の contamination 受けた日のと考光ら教例が多い。移植結節は 2 例，Q

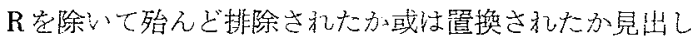

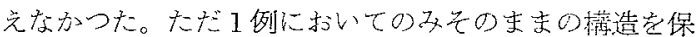
つて凝固壊死に陷入り，また他のI例Qに光いては移稙

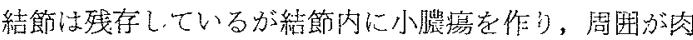
芽織で被包さ诿ている。他方1例に方いては移植結節は ないが中心に浐死を誌めた。表 3-7において特殊な大単

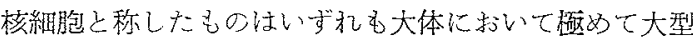

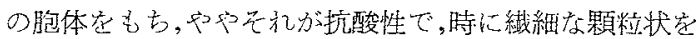
示している。核は円形ないし類円形で，クロマチンは中 等度，時にやや細長い形をとることもあるもの空総称し たものである。こ㣗はいずれの例においても著明に出現 し，とこるによつては集簇している部分もある。類上皮 細胞は人体に見られる如き定型的なものは少ないが，い

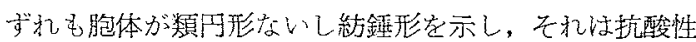

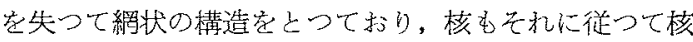
膜が判然としてクロマチンは少なく1〜2個，朋瞭な核 小体宗すものを称している。これらの類上皮細胞は約
半数例において割合に著明な出現を示しているが，他の 例で涂り類上皮細胞は判然としない。回形細胞浸溜は 体重の多い請では著明なものもあつたが，体重の低い群 では前者に較べて少なかつた。巨細胞はほとんど全例に おいてその出現が認められたが，てれらの巨細胞は定型 的なラングハンス型ないし異物型を宗すことなく，非常 に変化に䔰えだ巨細胞で中には巨核の巨細胞も混じてい t。

リンパ節においてはこれら長期実験群はいずれも著明 な变化を示し，二次小節，明中心の出現，堌加等は全例 において認められ，中に湆核定伴つた割合に定型的な 二次小節も見られる。また，全列を通じて著明な変化

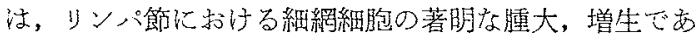
る。こ和らはいずれもやや集簇の傾向学示に，本筫的に は皮下移植結節部心見られた特殊な大単核細胞と同一の

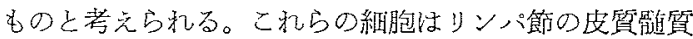
のみならず，迅縁洞盛炕も充渻している像が見られた。

菌染色所罗によると，上記の皮下結節劣よびリン八節

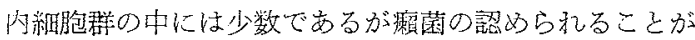
多く，委た定型的桿菌の態を示与ことなく，颗粒状或は

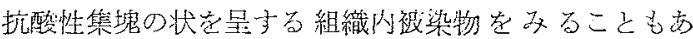
万。

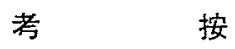

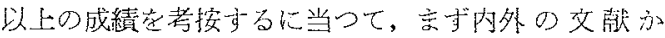

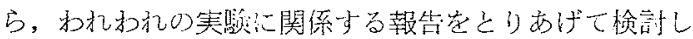
てみたい。

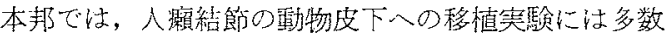
の業績があるが，その中，動物の感受性取报つたもの

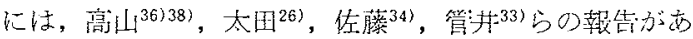

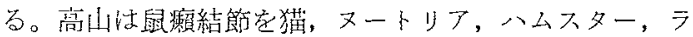
ッデな゙に単純移植或はその乳剂の移植学行い，八厶ス

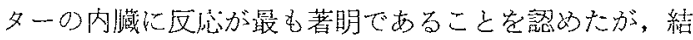
論的には感染の不成立定諭点としている。太田 ${ }^{26)}$ ルモットを除くねず数，猿類，鳥類に広沉な人攋結節

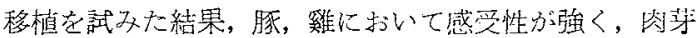

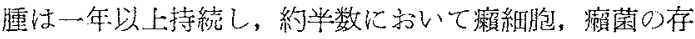

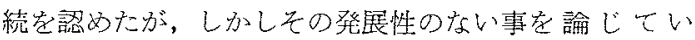
る。同様の実駼定行つた佐藤 ${ }^{34)}$ によれば，家䌖，猿， ッテ，マウスでは感受性があるが，モルモットでは感受 性がなく，モルモットは人攋の実験動物として不適当で あるといら。

渡辺 ${ }^{40)}$ 恃人瀨結節范ラッテの皮下に移禃した場合，癩 菌は一定度まで增殖傾问在示し，リンパ節に異物結節度 
作り，その部に巨細胞老認为るが，漸次菌染色性不良と なることを誌め，主として菌染色性の面から移植の可否 を論じた。

菅井 ${ }^{333}$ はモルモットの腹腔内に人濑結節の接種を行い 21日目に殿殺してその病理組織像について退べている。

実験勒物认種々の処置甞加え，その処置後に移植空試

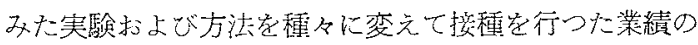
中, 主尔ものに安田 ${ }^{42)}$, 池谷 ${ }^{13)}$, 谷村 ${ }^{357}$, 渡边 ${ }^{41)}$, 高山

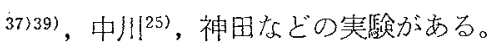

その中, 安田 ${ }^{42}$ は八ブ毒加家雨兔疫血清の前処置䘮行 い,その㯖腔内に人瘊結節を擂入与尚という高木氏法で

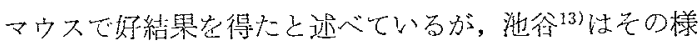
な処置定行つたものと対照群とに差はないとして安田の

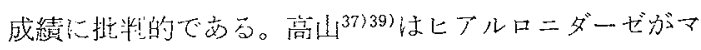

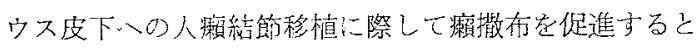
述べ，さらにX楾照射後，コーチゾン投与执よびコーチ

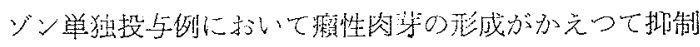

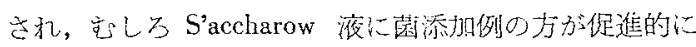
働くと述べ，さらに Toluidin-Blau 就よ゙明格にはこの ような肉芽形成促進能はないとしている。中川 ${ }^{257}$ の特頡 下腺ムチン前処置, 太国氏液コブラ毒等の処員マウスの

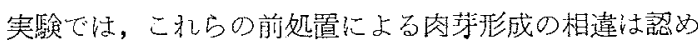
ら记ていない。

接種方法ふよざ接程部位索唡討した成縝として，谷村

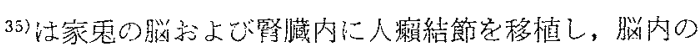

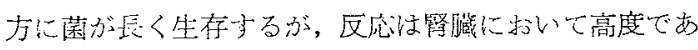
るとし，また，渡辺 ${ }^{41)}$ はラッテの皮下，血管，等丸，腹

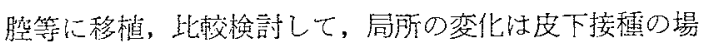

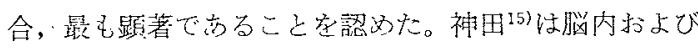

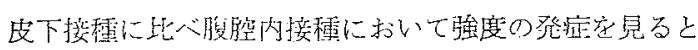
しているが，この接種方法乞は别に纱若マウスと成熟マ

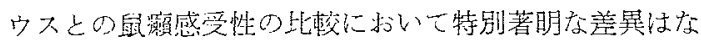
く，隽命上り主光しろ便体差の影響を重視している。

以上沵本邦の交献に見られる主なるこの領域の業績で あるが，外国でもこの程の坏告は枚举に遈がなく，殊に 最近では Cochrane,5) Feldman,5) Melsom ${ }^{22)}$ 等, 或は 脾の剔出， $\gamma$ 線照射，下垂体の剔出，Alloxan の使用， Silicon の使用, Lipid の使用など, 種々の実験操作を とり入れているものが多いが，て礼らの中，Feldman ${ }^{5)}$ 名1956年に人癞の移植実験に関しての綜説它試子ている が特に注目に価する。

彼はその綜説の中で，まず人攧病変が皮簓と神経に偏

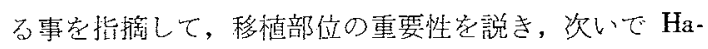

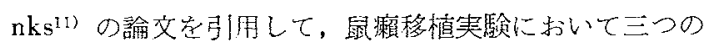

因子、与なるっ，

1）菌が保持している固有の宿主に対する適心の度合

2)接種動物に対与る組織構成の adverse-effect

3）宿主側の抵抗の役割が重要である

ことを述べている。さらに Properdin ${ }^{30)}$ の䦎題にられた

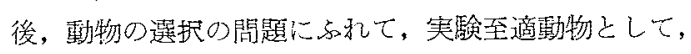
チンパソヂー, シリアンゴールド・八ムスター, 仔豚, ホよび质牛の四程を最も適した実驗動物としているが，

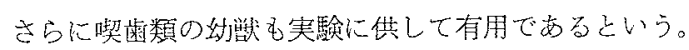

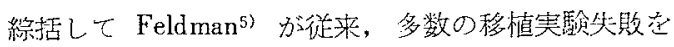

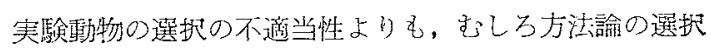
の誤謬にあると遮べているのは，傎㯖に価すると思すれ る。

以上, 举げた諸報告中, 移植部位の病理組織学的所見

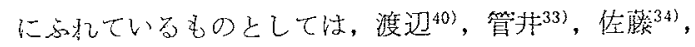

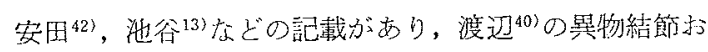
よび巨縕胞形成の記述, 佐藤 ${ }^{34}$ の Tuberculoid-type 形成 所見に基く Leprose-Tuberkel の提唱, 安田 ${ }^{421}$ のマウス

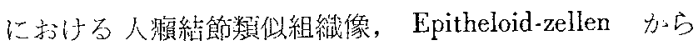
Lepra-zellen 形成の所見などが注見されるが，いずれも 組織所見は精細を欠いて, 平板な記載に止つている。菅 壮 ${ }^{33}$ の報ずる、人癩結節股腔内接程 21 日目の所晃は被移植 動物がモルモットである点で參考にしうるが，しかし，

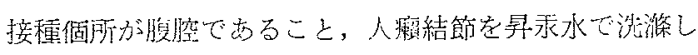
ていること，また実歌口数が短い事などの点で，わ机わ 秃の実験とは趣装にする。

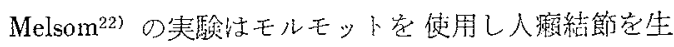

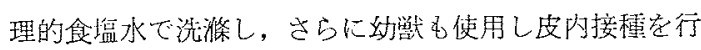
つている点で，われわれの実験に類促して柇り，この場

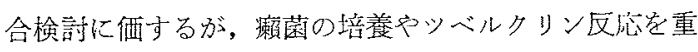
視し，病理組織学的変化については癩の特性を偖えた緼 織像, 例兄ば瀨球の存在, 類上皮細胞の存在, 菌の局所 ソンパ節への撒布於よび類上皮泪胞の出現などの籍単な 記載があるのみで，組織反芯全般については全く触れる ところがない。

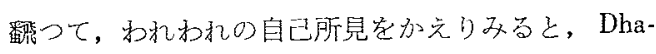
rmendra 皮内反応湆性で，組織学上 Lepromatous-Type の像をとる人瀨結節をモルモット皮下に移植する場合，

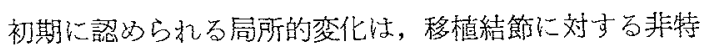
異的炎症像であつて出現象主主体とし，やがて，結節 自体の壊死, 好中球による貧食定へて, 器化比赴く一連 の過程である。この場合，幼獣と成獣とを比較すると，

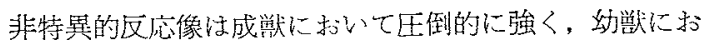
いて弱い。しかして棐特異性反态が強烈である場合には 
移植結節自体の墎死と共に結節中に含まれる藾菌もまた 自減し，あるい忹盛な好中球性貪食を蒙つて，反応は 単なる非特異性異物性炎の形を呈して終熄に至るけれど も，ことに幼獣において非特異性反応汃徽弱に経過子る 場合には，結節内に含宋れる瀨菌は結節組織の一定度の 融解扎よび出液の組織内移動に伴つて，一旦，宿主側 皮下組織内に放出され，その場で一旦隇少する(移植後 72時問前後)けれども，やがて明らか增殖に転じて， 30 日以後次第比明確度をむ種の特殊肉茅の形成を促 す。この初期沈おける一過性の菌の減少は培養時:の Lagphase に擬して解碾することが出来る。

後期に至つて以上の経過で出現する特殊性反忘の形態 学的性格は成績の章下に詳述した通りで西るが，その像 以凡之 Büngeler4) の所謂 uncharakteristische-infiltrat 汅至 Prä-tuberculid に一致する uncharakteristischeinfiltrat の像は人体初期感染例で，臨床的に Achromie 或は Hypochromie の状態にある表皮に認められ， Büngeler")によればこの状態からさらに Prä-tuberculoidtype を経て Tuberculoid-Typeに至るかまたは治瘾に赴 く。場合によりその初期状態から Lepromaに転ずるこ とむあるという。この特殊肉芽性反心漈して出現し， 移植結節から放出された菌索掑取し，反応の中核它成す 単核細胞の由来に関して, 赤崎，小島および緒方27)等は 賦活化されてた組織球と見，Oliver29) も立た生体染色所 見から組織球起原説をとつている。他方, 細胞免度論の 立場汃らは義汇 ${ }^{43)}$ の如く単求説をとるものもあつて，こ の間の経緯は結核の場合に抢ける類上皮細胞起原に関す る組織球，単球酕論と等しい。いずれにして子特殊肉芽 性反応の後期汇は，乙れら峃球緙胞化し，結節状に配列 する所見にしばしば接する。ただし，われるれい場合類 上皮細胞の形態は人体のそれに此へて定型的でなく，結 節の形状を不完全で㪍酪化をみることが少い。その意味 で性 Lurie17) の所謂, Nodular-phase 分完成されている とは考えにくい。

以上の所見を通観すると，しかしながら，人癞結節を 幼若モルモットに移植する場合，組織反心としては明ら かに特殊性肉荽の形成を見，方つ，所属少ンパ節にも特 異な病像を呈することに疑いはない。

Lurie の Mycobactrium の組織反応二相説は菌と宿主 との関䋆考慮して Symbiotic-phase と Nodular-phase の二相を区別して考え，瀨に打ける Lepromatous-Types は前者に，Tuberculoide-Type 洼㣪者に相忘与る組織反 応であると見る。

Tubercloid - Type が一般に特異的並びに非特異的免度
および抵括を有する個体における痛の病型として現わ れ，Lepromatous-Type はこれに対し免度を欠き，ま たより抵抗の弱い值体に拉いて出現することに関して は臨床上および夷唡病理学上，多数の知見がある。

この場合，癞の痕型決定に関与する缩主側の抵抗力を 具体的にどの樣な条件に求める加について多くの説が

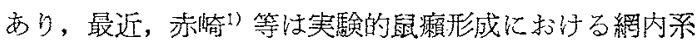
機能について, T A クチン, エバンス・ブルー,カル ジオリピンの注射によつて網内系機能が䟼后されている ときは Tuberculoid-Type をとり，䋧内系機能が低下す る場合には Lepromatous-Type をとることを正べ，また Lepromatous-Type の衁清中カルジオリピンの存在する ことから嬾の組織反応型と網内梁機能との関係を考察し ている。湯川，福士45)らはパロチンを鼠濑形成使使用 し,やはり網内系機能の亢進状態では赤崎”らと同一所 見に達した。

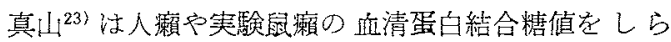
べ, Tuberculoid-Type では船清盆白には著変はないが, ただ， $\gamma$ 結合值の上昇をみている。

Lowe ${ }^{18)}$ によ杣瀨の二型は互に秋行することなく， 一方では感作並びに色梥を示し，一方ではそれらの完全 な欠如安示しており，特に Tuberculoid-Typeで免疫が高

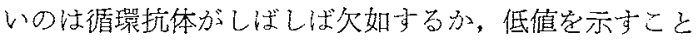
から感染の low-level 呈するもので西る己論じてい る。

われわれのモルモットにおける所見加らみると，本来

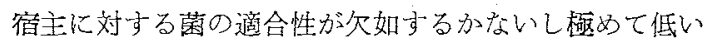
場合，本貿的には買物としての瀨菌および攋結節に対す る非特異性反忍が強く現われ，それが癭結節移植の可能 性を全く排除してし女う。しかしその非特異的な防禦反 応が微弱であるか方たは不完全な状態では瀨菌とモルモ ット組織との間に朋らが一定の相関関係が成立する。 その場合，組織像が Lepromatous-Type をとら宗いのは 加諭，また，Lurie の意味での Nodularphase にまでも

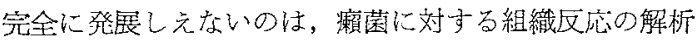

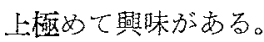

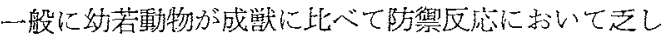
く，殊に炎症における济出性变化に費しいことは多くの 夷験があり，殊にその意味での一般的反心方の微弱状態 の一つの極限は無菌飼育動物 ${ }^{16) 19220) 211}$ に尔いて見出され る。

従つてわれわれの奏験から見秃ば，究極的無菌動物に おいて見られる無反五状態下にあつては菌の組織に対す る適応力が著しく低い場合でるその所謂, 弱毒菌に対し 
て一定の圆有の組織反応が成り立らうる可能性がある。

この意味ては Feldman ${ }^{5 》}$ が癩の移植実験に関して幼

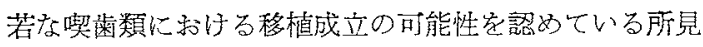
支持すること㳩出来る。

\section{結論}

国立らい療養所に补て Lepromatous-Leprosy の忠者 6名より人癩結節をなるべく鿏菌的に剔出し，生理的食 塩水を通し，モルモット成獣 32 匹，妙獣 34 匹の大腿内 側皮下に消毒の後, 皮切, 插入乙縫合, こ社24時間, 48 時閪，72時間，6日，10日，30日の短期実粭群と50 〜80日の長期実験群とに分けて移植実駼密行い，その病 理組織学的检索学行つた結果，

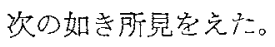

1）モルモットにおいて稳植された人潞結節は，当初，

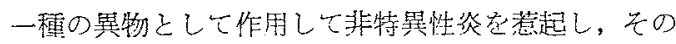

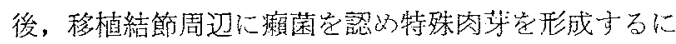

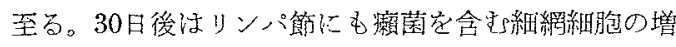
生它認好る。

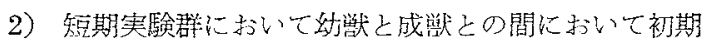
參出反心の差を認め，前者心方いて藷明であつた。

3）こ秃乙逆に插入結節は成獸に和いて早期に滲山区応

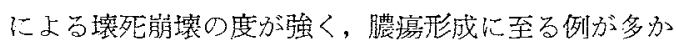
つた。

4) 移植 30 日後の結節周辺に形成された特殊肉茅は,

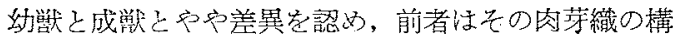

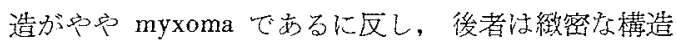
をとつている。

5）害駼6日目以後，巨細胞の形成案晃るが，これは当 初惊異物型巨細胞が多く，後に梳ラングハンス型巨紬 胞空混じ，さらに長期になると巨核の巨綥胞を認め zo

6）長期実驗群では円形細胞浸潤および一部は類上皮細 胞形成が見られる。

以上の実駼よりモルモットにおいてす癩菌を含导特殊 肉势の形成掞よびリンパ節人の撒布等の形成さ礼ること が認められた。

稿を終るに当り，御懇第な御指導を戴いた恩婂宮川 正澄教授，飯島 宗一助教授，岸本 英正博士及び国立 療荃所長島愛生園最 高息 重孝博士亚びに国立駘河療

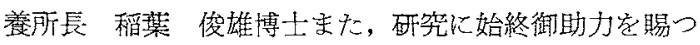
た名大第一涴理学教室医局員各位之国立駿河療羡所医官 各位に心から梁い感謝の意老表するのである。

\section{参考 文献}

1）赤崎兼義，綿貫 勤，木村辉炤；獺の病型と繹内 系機能状態との関係（㷋症発生譏構の基礎的綜合的

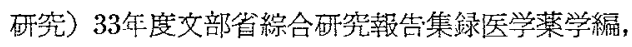
158真

2) S. Adler ; Inoculation of human leprosy into syrian hamster. Lancet. 2, 714 (1937)

3) C. H. Binford; VIIth International Lep. Cong. (1958)

4) W. Büngeler; Die patholegische Anatomie der Lepra. Virchow Archiv., 310, 493 (1943)

5) W. H. Feldman; Approaches for experimental transmission of human leprosy. Lep. Briefs. 1, 2 (1956)

6) J. H. Hanks; A study of the bacilli in tissue cultures of lepromata in serum Media. Internat.

J. Lep., 15, 21 30 (1947)

7) J. H. Hanks; The fate of Ieprosy bacilli in fibroblast cultivated from macular and tuberculoid lesions. Internat. J. lep., 15, 31 47 (1947)

8) J. H. Hanks; The fate of leprosy bacilli in fibroblast cultivated from Lepromatous lesions.

Internat. J. Lep., 15, 48 64 (1947)

9) J. H. Hanks; The question of free bacillary growth in the plasma surrounding lepromatous explants during tissue cultivation. Internat. J. Lep., 15, 67 69 (1947)

10) J. H. Hanks; Immunological and physiological Aspects of immunization in tuberculosis and lerosy. Ciba F. S. on Exp. Tub. J. \& A. Churchill London (1955)

11) J. H. Hanks; Three factors which may influence the experimental transmission of leprosy. Internat. J. Lep., 18, 33 47 (1950)

12）石原重德, 萩原鐘一; 攋組織のパラフイン切片㯲 本における菌染色，レプラ，23，143～146（1954）

13）㴰谷竜夫；癩菌の研究，レプラ， 12, 469〜 538 (1941)

14) C. M. Carpenter; The separation of M. Leprae from tissue by enzyme-digestion. Am. Rev. Tbc 74, 152 (1956)

15）神田幸重他；幼若マウスの鼠癩の感受性について レプラ, 22, 135 (1953) 
16）木俣 瑟；自然動物に於ける異物（海綿）性炎の 研究一重菌動物に於ける異物性炎乙の比较, 名古屋 医学, 76, 12 (昭33)

17) M. B. Lurie; A pathogenetive relationship between tuberculosis and leprosy; The commom denomination in the tissue response to Mycobacteria. Ciba F. S. on Exp. Tub. J. \& A. Churchill London (1955)

18) I. Lowe; The leprosy bacillus and the host reaction to it. Ciba F. S. on Exp. Tub. J. \& A. Churchill London (1955)

19）宮川正澄；炎晸反応の基本態度とその基盤，日本 隐㕅, 15, (9), 14（昭32)

20）宮川正澄；無菌飼育動物の炎症，日典会誌（第19 回学会号) 20, (3)，88〜97 (昭33)

21）宮川正澄；自然動物に於ける炎症発起の基盤につ いて, 最新医誉・ $\mathbf{1 3}$ （4）, 38 (昭33)

22) R. Melsom; Experiment in inoculating guinea pigs with Ieprous material. Acta Dermat. Venerrol 20 : 451,462 (1939)

23）真山旭；人瀨及び実験鼠瀨に於ける热清蛋白結 合糖質に就いて，レプラ，26，160〜165（1957）

24）中村昌弘; 鼠濑菌の菌体成分に関子万研究, 第三 報 トリプシン消化感染皮下組織より集菌した菌体 の構成成分について，レプラ，26，1〜7（1957）

25）中川 洋, 中村昌弘; 人瀨の動物実験に関する研 究，レプラ，23，293〜296 (1954)

26）太因正雄; 攋の動物実験に就て（抄淾）レプラ, 52頁, 10 (1939)

27）緒方知三郎; 癩病理の二, 三の知見, 殊に病型問 題について，医学のあゆみ，26，1（昭33）

28）緒方知三郎；第 15 回日本医学会総会（特別講演） (昭34)

29) J. Oliver; Origin of lepra cell. J. Exp. Med. 43, 233 (1926)

30) Pillemer; The properdin system and immunity science, $120 ; 279$ (1954)

31）清水富士雄；末㮐神経に於ける瀨菌の營光顕微鏡
裴置（矢㱦式）に依る検索と組織学的所㫕，日病会 誌, 42 (総会号) (昭28)

32）清水富士雄；螢光顕微鏡装置（矢崎式）に依る内 荿癩病栄の癩菌検索とその組織学的所見, 日病会誌 $47,145 \sim 160$ (昭33)

33）营抄竹吉；癩病に対する動物の感受性研究（第一 回報告）東宗医学会報，16；761（明治35）

34）佐藤三郎；瀨の﨡物接程試験，日新医学，32, 772 (昭18)

35）谷村忠保，桜根好之助；瀨結節の移植に関する実 験的研究（其一) レプラ，1，13〜28（1930）

36）高山保郎；攋菌の異種動物接種火関卞る研究（第 一報）八ムスターの鼠湘菌に対する感受性，レプラ 22, 131 134. (1953)

37）高山保郎；濑菌の異霾動物接種に関与る矿等（第 二報）人癩菌接種マウスに及占す Hyaluronidase の 影響，レプラ，23，15〜17（1954）

38）高山保郎；獺菌の異種動物接種に関主名研究（第 三報）猫及びヌートリフの罗癩菌に対する感受性に ついて, レプラ, 25, 147〜158 (1956)

39）高山保郎；鼠癩発症に及ぼすX線照射亚びに Cortisone その他の投与の影響について，レプラ，26， $8 \sim 14$ (1957)

40）渡辺義政；瀨動物試鉭（第 2 報告）人攋感染試験 （其一）細称学雑誌，460，401（昭 9)

41）渡辺義政；瀨動物試験（第11回啹告）人瀨感染試 豎（其三，ラッテ）レプラ, 15, 1〜11（1944）

42）安田忠次郎；獺の感染発㱏譏転に関する実験的研 究, レプラ, 15, 169〜187 (1944)

43）義汇義雄; 攋繦胞及び類結核性獭变化の形成に関 する研究 (第一報) レプラ，20，164〜165（1951）

44) 義汇義雄; らい研究の進歩, 最新医学, 12, 17一 24. (昭32)

45）湯川 智, 福士勝成; 唾液腺ホルモンのソライ腫 形成に対与古影響についての病理組織学的研究, 日 病会誌, 47, 420 421 (昭33)

46）第 5 回国際ら以会議録 Havana (1948)

47）第6 回国際らい会議録 Madrid (1953) 
写䔬 锐 明

Fig. 1 移植原結節の一例 患者 二0春 0 短期实験群

Fig. 2 移㥀後 48 時間 成獣

Fig. 3 移植後 72 時間 幼獣

Fig. 4 移植後 $10 \mathrm{H}$ 奻獣

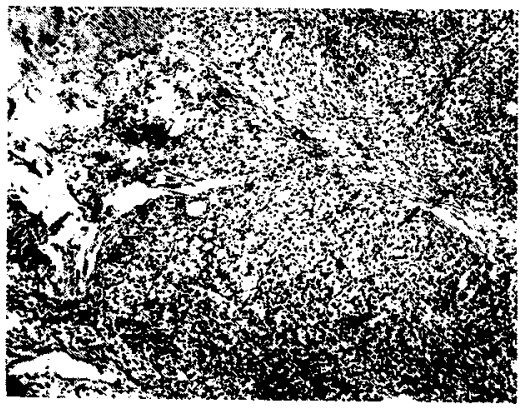

Fig. 1

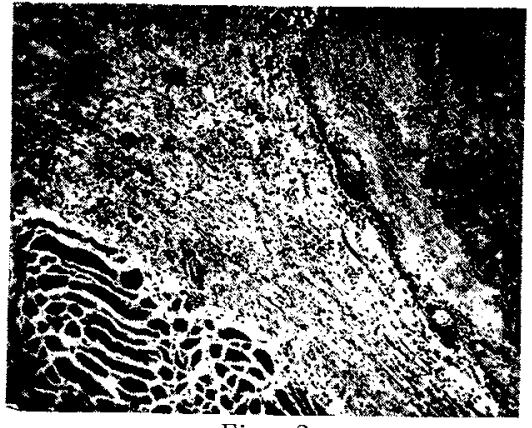

Fig. 2
Fig. 5 移植後 10 日 成獣

Fig. 6 移植後 30 日 幻獣

Fig. 7 移植後 30 日 成獣 長期実鈳群

Fig. 8 移植後 55 日

Fig. 9 移植後 60 日

Fig. 10 移植後 55 日0所属リンハ節

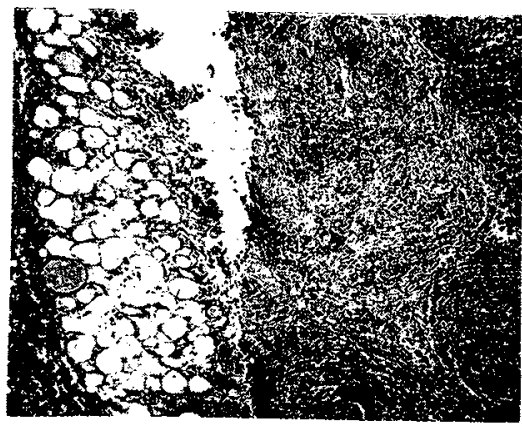

Fig. 3

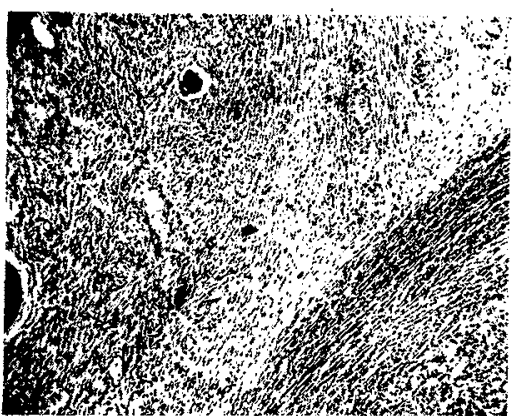

Fig. 4 


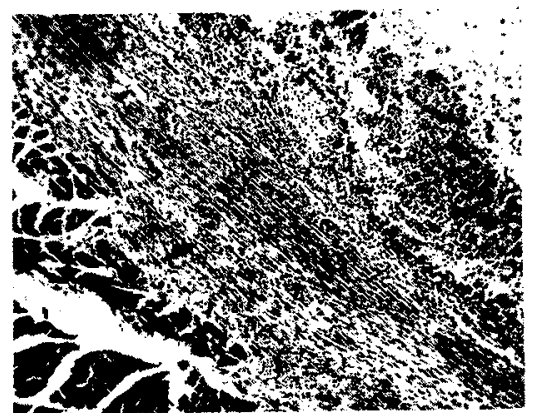

Fig. 5

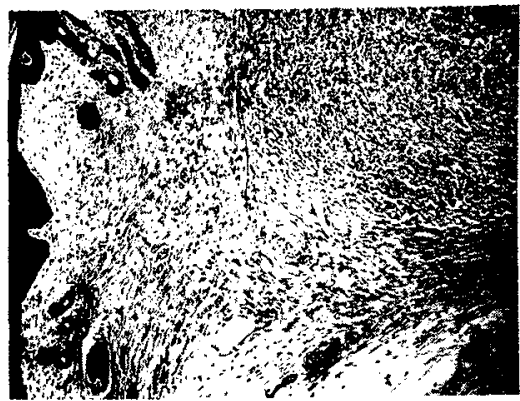

Fig. 6

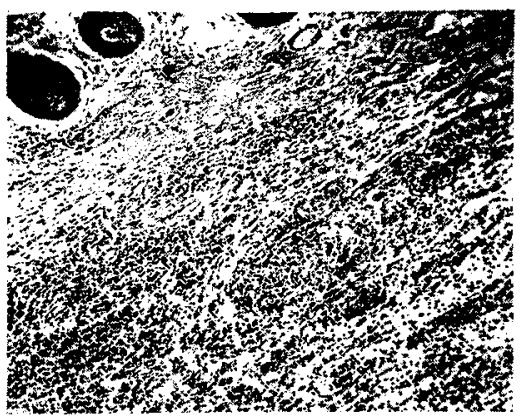

Fig. 8

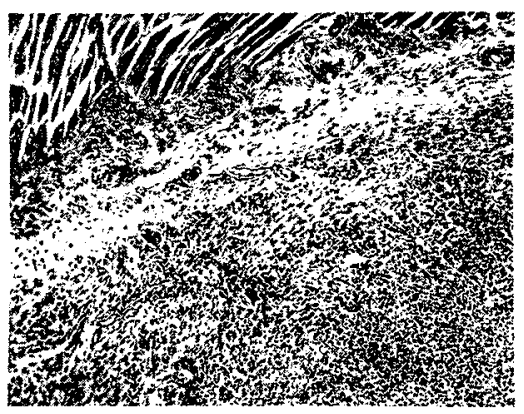

Fig. 9

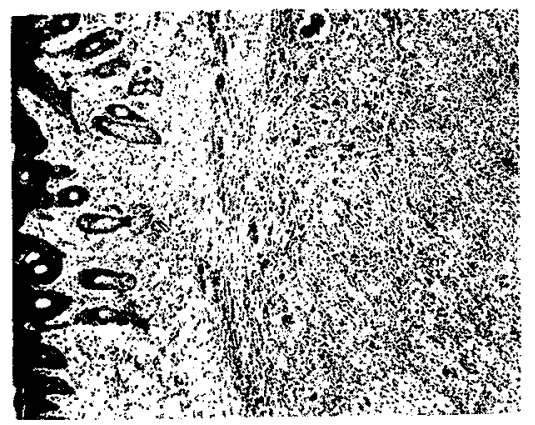

Fig. 7

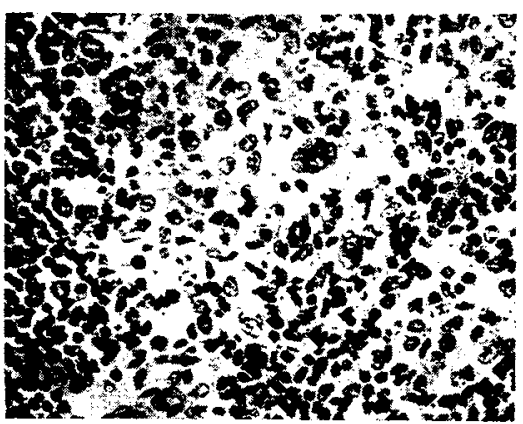

Fig. 10 